\title{
Relationship among Economic Growth and other Macroeconomic Variables: A Study of Pakistan
}

\author{
Musarrat Shamshir \\ Greenwich University, DK-10, 38 Street, Darakshan, Phase VI, Defence Housing Authority, Karachi-75500, \\ Pakistan \\ Nazia Abdul Rehman \\ Hamdard University, Madinat al Hikmah, Shara-e Said, Karachi, Pakistan
}

Adnan Hussain

Benazir Bhutto Shaheed University Layari, Karachi.

Samina Sabir

University of Azad Jammu and Kashmir, Muzaffarabad.

\begin{abstract}
This study is investigating the short run and long run relationship among major macroeconomic variables and economic growth for the economy of Pakistan during 2000 - 2015. Autoregressive distributed lag (ARDL) model and bounds test have been applied to estimate the short run and long run relationship between GDP and other major macroeconomic variables like, labour force, rate of capital formation, money supply, inflation rate, trade rate, foreign direct investment (FDI) and unemployment. ARDL model indicates significant relationship between labour force, FDI and unemployment economic growth, in the long run, at $1 \%$ and $5 \%$ level.

Keywords: Macroeconomic variables; capital formation; money supply; inflation; trade; FDI; unemployment; economic growth; ARDL model.

JEL Code: O1; O4; F43.

DOI: $10.7176 / \mathrm{JRDM} / 54-07$

Publication date: April $30^{\text {th }} 2019$

\section{Introduction}

For the economic development of the countries, one cannot rule out the importance of the rate at which the gross domestic product (GDP) is growing (Barro, 2004). The macroeconomic variables like rate of inflation, money supply, investment trade openness etc., are the major determining factors of GDP. A number of researches have been conducted to estimate the association of GDP with major macroeconomic variables, but very few studies are focused on the nature of relationship and intertemporal linkages between the variables. Similarly, traditional theories have established the relationship between certain variables, for e.g., consumption and saving model is based on income theory; however, these theories have failed to explore the connection of capital accumulation to saving. Another, aspect of exploring the nature of connection between; for e.g., labour force participation rate may be attributed to the investment policies adopted for domestic and foreign investment. Foreign direct investment and GDP are positively associated; as projects with huge investment can be started through FDI (Yaqub, Ali \& Haq, 2016). Low productivity may be associated by strategic planning for catering inflation but at the same time may also impact the tax revenue causing budget deficit in the country. Similarly, net exports are dependent on GDP levels and increasing reliance on imports may distort the trade balance.

Pakistan being a developing economy has always been aiming balanced trade and budget accounts; striving for investment, employment and to realize real economic growth in the economy (Kibria, Arshad, Kamran \& Mehmood, 2014). The importance of exploring the nature of the nexus between the key macroeconomic indicators like labour force, capital formation rate, money supply, inflation, trade volume, foreign direct investment and unemployment and economic growth is the compelling force behind this study. This study considers the annual growth rates of the variables mentioned above from 2000-2015 to examine the association between the said variables. Mostly previous studies on Pakistan have relied on cross-sectional and panel data to
\end{abstract}


contemplate the connection. This study is the departure from past studies as it uses the time series data to examine the temporal relationship between the variables.

\section{Literature Review}

The researchers are continuously trying to determine the intensity and existence of correlation among the various macroeconomic indicators and their impact on the economic growth of the country. The results reveal mixed patterns in developed and developing nations that are further diversified with the techniques and tools adopted in various studies.

Hypothesis about exports impact on countries economic growth was proved by the data of 43 developing countries from the period of 1973 to 1978, at the time when these countries faced oil shocks (Balassa, 1985).

Hasanov (2011) conducted a study on Azerbaijan's economy and found the positive relationship between inflation and economic growth till threshold level of $13 \%$ and negative thereafter.

Stamatiou and Dritsakis (2013) investigated five Eurozone countries for causality between foreign direct investment and economic growth by using panel data and found two-way causality between exports and economic growth, however, with no causality between economic growth and FDI.

Mosikari (2013) tested causal relationship between unemployment and gross domestic product (GDP) in South Africa by taking time series annual data from 1980-2011. The study found variables to be stationary at first difference. Moreover, granger causality test reveal absence of causality between unemployment and GDP growth. However, study found long run relationship between variables; thus, encouraging long run policies towards growth favouring employment.

Saymeh and Orabi (2013) tested the time series data of Jordan's economy over the period of 2000-2010. The study employed unit root test, co-integration test, Grange causality, ARCH effect and GARCH model for investigating the causal relation between interest rate, inflation, GDP and real growth rate. The result reveals that inflation causes interest rate and interest rate has an impact on growth rate; 0 implies inflation affects economic growth.

Pradhan, Arvin, Hall \& Bahmani (2014) conducted a study of ASEAN economies to determine the connection between GDP with financial variables and four other macroeconomic variables including inflation, trade openness, foreign direct investment and government consumption expenditures and found unidirectional and bidirectional relationship between the variables.

Saeed and Hussain (2015) found granger causality between import and exports and found one-way casualty between exports and economic growth in Tunisia over the time period of 1977-2012. The study employed Augmented Dickey-Fuller (ADF) and Phillip-Perron (PP) stationary test for long run relationship evaluation.

Yelwa, David \& Awe (2015) found significant impact of interest rate and total expenditure on economic growth in the long run, while an inverse effect of inflation and unemployment on economic growth was established for Nigerian economy (Ademola \& Badiru, 2016).

\subsection{Empirical Evidence for Pakistan}

Several studies have been conducted with mixed results found for Pakistan's economy. For example; Falki (2009) found negative impact of FDI on economic growth, while Ali (2014) depicted positive significant relationship between the two. Similarly, Ullah, Shah \& Khan (2014) adopted Toda- Yamamoto causality approach and found long run significant results between domestic and foreign investment and economic growth. Moreover, Ilyas, Sabir, Shehzadi \& Shoukat (2014) found no significant relation between saving and Inflation while negative relation between inflation and growth. On the other hand, Shahid (2014) determined positive relation between inflation and economic growth by time series analysis. Before that Mahmood, Bokhari \& Aslam (2013) examined association between the inflation, interest rate and unemployment rate and tested quarterly time series data of Pakistan economy over the period of 1992-Q ${ }_{1}$ to 2011-Q 2 . Employing Johansen's cointegration and vector error correction model the study established that inflation; investment and unemployment rates are co-integrated. Yaqub et al. (2016) tested the Pakistan's economic data of the period of 1990-2012 and depicted FDI and economic growth relationship through techniques of ordinary least square and unit root test.

Abbas (2012) tested short and long run causality between production growth and exports for the period of 1975 to 2010 on Pakistan's economy and found growth in production causing growth in exports. Similarly, Hameed, Iqbal \& Devi (2012) tested the association of exports and Pakistan economic growth for the period between 1960 to 2009 through Granger causality test and found unidirectional causality between GDP and exports. 
This study is different from all other studies conducted, one; the study is taking 40 years of data into consideration which will enable to evaluate the significance of variables over long run, two; monetary variables like money supply, capital formation are included in the study which have not been considered in any study so far for the correlation with economic growth three; the study is considering time series analysis unlike other major studies done before. This study will be able to depict the true estimates of causality coefficients after considering money market variables.

\section{Data and Methodology}

This investigation entails annual time series data set covering the period from 2000 to 2015.The time series data of economic indicators of Pakistan's economy collected from data bank of World Bank and international financial statistics (IFS) published by international monetary fund (IMF).

\subsection{Hypothesis}

$H_{1}$ : Labour force participation rate has a significant effect on economic growth in Pakistan.

$\mathrm{H}_{2}$ : Capital formation has a significant effect on economic growth in Pakistan.

$H_{3}$ : Supply of money has a significant effect on economic growth in Pakistan.

$\mathrm{H}_{4}$ : Inflation has a significant effect on economic growth in Pakistan.

$H_{5}$ : Trade rate has a significant effect on economic growth in Pakistan.

$H_{6}$ : Foreign direct investment has a significant effect on economic growth in Pakistan.

$H_{7}$ : Unemployment rate has a significant effect on economic growth in Pakistan.

3.2 Model Specification

The study uses the multivariable regression model for Cobb Douglas production function (Cobb, 1928),

$Y=f(L, K)$

Money supply $\left(M_{2}\right)$, Trade $(T R)$, foreign direct investment $(F D I)$, and unemployment (UNEMP) have been added to see the impact of money market, inflation and international trade in an open economy of Pakistan. The variable labour is represented by labour force participation rate and capital is presented by domestic gross capital formation and foreign direct investment.

$Y=f\left(L F P, C F, M_{2}, I N F, T R, F D I, U N E M P\right)$

Where,

$Y=$ Economic growth (GDP) in annual \% age

$L F P=$ Labor force participation rate ( $\%$ age of total population)

$C F=$ Gross capital formation (annual $\%$ age growth)

$M_{2}=$ Money supply (annual \% age)

$I N F=$ Inflation (annual $\%$ age)

$T R=$ Trade (export-import/GDP) (\%age of GDP)

$F D I=$ Foreign direct Investment $(\%$ age of GDP)

UNEMP = Unemployment $(\%$ age of total labor force)

$Y=\beta_{0}+\beta_{1} L F P+\beta_{2} C F+\beta_{3} M_{2}+\beta_{4} I N F+\beta_{5} T R+\beta_{6} F D I+\beta_{7} U N E M P+u t$

\subsection{Unit Root Test}

Unit root test is applied for checking stochastic properties of the variables. Although ARDL co-integration model does not call for pre-testing for stationarity condition, still to evade the chances ofARDL model crash in the presence of integrated stochastic trend greater than $\mathrm{I}(1)$, it is recommended to test number of unit roots present in the data series of selected variables in the study.

$Y_{t}=\rho Y_{t-1}+u_{t}$

The value of $\rho$ lies between -1 to +1 ,

$Y_{t}-Y_{t-1}=\rho Y_{t-1}-Y_{t-1}+u_{t}$ 
$Y_{t}-Y_{t-1}=(\rho-1) Y_{t-1}+u_{t}$

$\Delta Y_{t-1}=\delta Y_{t-1}+u_{t}$

The null hypothesis is $\delta=0$. If $\delta=0$ then $\rho=1$ implies that $Y$ is not stationary and has unit root. The above equation suggests that the first difference of an arbitrary time series is stationary.

\subsection{Autoregressive Distributed-lagged (ARDL) model}

The ARDL testing methodology of Pesaran and Shin (1999) and Pesaran et al. (2001) is a more grasping approach to the estimation of the series with a mix of stationary at level I (0) and stationary at first difference, for better results of short run and long run.

$$
\begin{aligned}
& \Delta Y=C+\sum_{i=1}^{n} Y_{1} \Delta Y_{\mathrm{t}-1}+\sum_{i=0}^{n} \gamma_{2} \Delta L F P_{\mathrm{t}-1}+\sum_{i=0}^{n} \gamma_{3} \Delta C F_{\mathrm{t}-1}+\sum_{i=0}^{n} \gamma_{4} \Delta M 2_{\mathrm{t}-1}+\sum_{i=0}^{n} \gamma_{5} \Delta I N F_{\mathrm{t}-1}+ \\
& \sum_{i=0}^{n} \gamma_{6} \Delta T R_{\mathrm{t}-1}+\sum_{i=0}^{n} \gamma_{7} \Delta F D I_{\mathrm{t}-1}+\sum_{i=0}^{n} \gamma_{8} \Delta U N E M P_{\mathrm{t}-1}+\varphi_{1} L F P_{\mathrm{t}-1}+\varphi_{2} C F_{\mathrm{t}-1}+\varphi_{3} M 2_{\mathrm{t}-1}+ \\
& \varphi_{4} I N F_{\mathrm{t}-1}+\varphi_{5} T R_{\mathrm{t}-1}+\varphi_{6} F D I_{\mathrm{t}-1}+\varphi_{7} U N E M P_{\mathrm{t}-1}+\varepsilon_{\mathrm{t}}
\end{aligned}
$$

Where, $\gamma_{1}, \gamma_{2}, \gamma_{3}, \gamma_{4}, \gamma_{5}, \gamma_{6}, \gamma_{7}$ is the short run and $\varphi_{1}, \varphi_{2}, \varphi_{3}, \varphi_{4}, \varphi_{5}, \varphi_{6}, \varphi_{7}$ are the long run dynamics estimates of this test is:

$H_{0}: \varphi_{1}=\varphi_{2}=\varphi_{3}=\varphi_{4}=\varphi_{5}=\varphi_{6}=\varphi_{7}=0$

$H_{1}: \varphi_{1} \neq \varphi_{2} \neq \varphi_{3} \neq \varphi_{4} \neq \varphi_{5} \neq \varphi_{6} \neq \varphi_{7} \neq 0$

Bound test is used to see if long-run relationships are present among series integrated of different orders less than I(2). Moreover, bound test reiterates the hypothesis of long run stable equilibrium cointegration among variables (Omoniyi and Olawale, 2015). If the F-statistics falls below the lower bound, it implies rejection of null hypothesis and existence of cointegration is concluded when F-statistics exceeds the upper bound. On the other hand, if the F-statistic falls between the bounds, the test is inconclusive.

\section{Empirical Results}

\subsection{Descriptive Statistics}

Table 1 reveals highest mean value 42.32 for labour force participation rate reflects the working age population in the economy while lowest mean value (0.78) for FDI. Money supply has a maximum standard deviation 6.98 , indicates the volatility in money supply in contrast with minimum standard deviation (0.79) for FDI. The data series of labour force, trade and unemployment shows negative skewness, while GDP, capital formation, money supply, inflation and FDI reflects positively skewed data series. Labour force, capital formation, money supply, inflation and FDI are leptokurtic showing the presence of outliers in the series, whereas and GDP, trade and unemployment are platykurtic. Higher values of Jarqa-Bera reflect absence of normality in the data series of labor force, money supply and FDI. On the other hand, GDP, capital formation, inflation, trade and unemployment shows signs of normally distributed time series.

\section{Table 1 Descriptive Statistics}

\begin{tabular}{lccccccc}
\hline Variable & No. of Obs. & Mean & Std. Dev & Skewness & Kurtosis & Jarqua-Bera & Prob. \\
\hline GDP & 16 & 4.0122 & 1.9873 & 0.3507 & 3.0262 & 0.6957 & 0.7836 \\
LF & 16 & 42.3145 & 2.9964 & -4.7876 & 28.0210 & 1234.0110 & 0.0000 \\
CF & 16 & 4.1229 & 5.8995 & 0.2033 & 3.5068 & 0.8357 & 0.7598 \\
M2 & 16 & 16.0245 & 6.9872 & 1.6720 & 8.542 & 57.1379 & 0.0000 \\
INF & 16 & 7.9452 & 3.7102 & 0.7390 & 4.4098 & 5.7833 & 0.0831 \\
TR & 16 & 32.8910 & 3.8922 & -0.4985 & 3.4645 & 2.0444 & 0.4766 \\
FDI & 16 & 0.7814 & 0.7986 & 2.9980 & 6.9549 & 58.9956 & 0.0000 \\
UNEMP & 16 & 3.9537 & 1.2379 & -0.0667 & 2.5888 & 0.8057 & 0.6648 \\
\hline
\end{tabular}




\subsection{Correlation Analysis}

Correlation matrix depicts the strength of the association of the variables. Table 2 indicates positive correlation of GDP with capital formation, money supply and trade and negative correlation with labour force, inflation, FDI, and unemployment. Similarly, labour force found to be negatively correlated to capital formation and trade. Results further reveal that capital formation and money supply seems to be negatively related with inflation, and inflation found to be negatively related to unemployment.

The results of previous studies indicate that inflation, unemployment and investment effects negatively on economic growth (Chughtai, Malik \& Aftab, 2015), but labour and capital positively effects on economic growth of Pakistan (Hussain, Siddiqi \& Iqbal, 2010).

Table 2 Correlation Matrix

\begin{tabular}{|c|c|c|c|c|c|c|c|c|}
\hline & GDP & LF & $\mathrm{CF}$ & M2 & INF & TR & FDI & UNEMP \\
\hline GDP & 1 & & & & & & & \\
\hline LF & -0.0466 & 1 & & & & & & \\
\hline CF & 0.4882 & -0.0235 & 1 & & & & & \\
\hline M2 & 0.2206 & 0.2191 & 0.3558 & 1 & & & & \\
\hline INF & -0.1928 & 0.0721 & -0.2165 & -0.0026 & 1 & & & \\
\hline TR & 0.0242 & -0.2003 & 0.0005 & 0.0768 & 0.4946 & 1 & & \\
\hline FDI & -0.1894 & 0.3326 & 0.0317 & 0.2062 & 0.3569 & 0.1958 & 1 & \\
\hline UNEMP & -0.2745 & 0.3342 & -0.1605 & 0.0021 & -0.1772 & -0.2064 & 0.3501 & 1 \\
\hline
\end{tabular}

Table 3 Unit Root Test

\begin{tabular}{|c|c|c|c|c|c|}
\hline \multirow[t]{2}{*}{ Variables } & \multicolumn{2}{|c|}{$\begin{array}{c}\text { Augmented Dickey-Fuller test } \\
\text { statistic (At Level) }\end{array}$} & \multicolumn{2}{|c|}{$\begin{array}{c}\text { Augmented Dickey-Fuller test } \\
\text { statistic (At First Difference) }\end{array}$} & \multirow[t]{2}{*}{ Integration } \\
\hline & t- values & Probability & t- values & Probability & \\
\hline GDP & -4.8752 & 0.0024 & --- & --- & $\mathrm{I}(0)$ \\
\hline LFP & -5.6304 & 0.0002 & --- & --- & $\mathrm{I}(0)$ \\
\hline $\mathbf{C F}$ & -5.5924 & 0.0002 & --- & --- & $\mathrm{I}(0)$ \\
\hline M2 & -5.4609 & 0.0004 & --- & --- & $\mathrm{I}(0)$ \\
\hline INF & -2.8585 & 0.1970 & -7.6898 & 0.0000 & I (1) \\
\hline TR & -2.3239 & 0.4169 & -7.4634 & 0.0000 & I (1) \\
\hline FDI & -3.2879 & 0.0888 & -4.1543 & 0.0118 & I (1) \\
\hline UNEMP & -2.5396 & 0.3360 & -7.5245 & 0.0000 & I (1) \\
\hline
\end{tabular}

4.3 Unit Root Test

Augmented Dickey Fuller (ADF) test is utilized to the identified unit root in the data. Table 3 depicts the results of Augmented Dickey Fuller unit root test. Labor force and money supply found to be stationary while, inflation, trade, foreign direct investment and unemployment are stationary at first difference. The date series of GDP, labour force, capital formation, money supply rejects the null hypothesis at $1 \%$ level of significance at level and the data series of inflation, trade and unemployment rejects the null hypothesis at first difference at $1 \%$ level of significance.

\subsection{Autoregressive Distributed Lag Model}

Table 4 shows the results of short run dynamics among economic growth and macroeconomics variables. The coefficient of error correction term (ECM) depicts the speed adjustment for long run equilibrium. The value of ECM defines how quick the adjustment process will be for the convergence of variables. Highly significant error correction term having negative sign reflects the stable long run relationship. The value of the ECM coefficient between 0 to -2 is good enough value depending upon the adjustment and flexibility capacity of the economy 
(Samargandi, Fidrmuc \& Ghosh, 2013). The coefficient value of ECM -1.07 implies that the speed of convergence is $107 \%$ in the following year.

Table 5 shows the existence of co-integration between the variables as the value of F- Statistics (3.27) is greater than upper bound at $10 \%$.

Table 4 ARDL Model for Short Run

Selected Model: ARDL (1, 1, 0, 0, 2, 0, 1, 0)

Dependent Variable: GDP

Included observations: 16

\begin{tabular}{lccc}
\hline Variable & Coefficient & Standard Error & Prob. \\
\hline D(LFP) & 0.1526 & 0.0899 & 0.1430 \\
D(CF) & 0.0436 & 0.0578 & 0.4920 \\
D(M2) & 0.0578 & 0.0512 & 0.2540 \\
D(INF) & 0.0791 & 0.1176 & 0.4970 \\
D(INF) & 0.3612 & 0.0942 & 0.0006 \\
D(TR) & -0.0496 & 0.1201 & 0.6789 \\
D(FDI) & 1.1498 & 0.7398 & 0.1342 \\
D(UNEMP) & -0.6320 & 0.2321 & 0.1081 \\
ECM (-1) & -1.0810 & 0.1761 & 0.0000 \\
\hline Table 5 Bound Test & & & Conclusion \\
\hline \multicolumn{1}{c}{ Equation } & F-Statistics Calculated & Upper Bound Critical Value & Co- integration exists \\
\hline GDPCLF,CF, $M_{2}$ &, & 3.13 & $(10 \%)$ \\
INF, TR, FDI, UNEMP & $(0.0278)$ & & \\
\hline
\end{tabular}

4.5 ARDL Model for Long Run

Long run association among GDP and macroeconomic variables is explored by ARDL model. Table 6 indicates significant positive relationship between labour force and economic growth while negative significant FDI and unemployment, in the long run, at $1 \%$ and $5 \%$ level.

Table 6 ARDL Model for Long Run

Selected Model: ARDL $(1,1,0,0,2,0,1,0)$

Dependent Variable: GDP

Included observations: 16

\begin{tabular}{lccc}
\hline Variable & Coefficient & Standard Error & Prob. \\
\hline LFP & 0.2656 & 0.1412 & 0.0722 \\
GF & 0.0362 & 0.0529 & 0.4812 \\
INF & 0.0543 & 0.0483 & 0.2414 \\
TR & -0.1403 & 0.1102 & 0.2174 \\
FDI & -0.0520 & 0.1149 & 0.6917 \\
UNEMP & -1.0562 & 0.4253 & 0.0230 \\
C & -0.6104 & 0.1922 & 0.0051 \\
\hline
\end{tabular}

\section{Conclusion}


This study is an attempt to investigate the long run relationship of major macroeconomic variables with economic growth for the economy of Pakistan during 2000 - 2015. Autoregressive distributed lag (ARDL) model with bounds have been applied to estimate the short run and long run relationship between GDP and labour force, rate of capital formation, money supply, inflation rate, trade rate, foreign direct investment (FDI) and unemployment. ARDL model indicates significant positive relationship between labour force and economic growth while negative significant with FDI and unemployment, in the long run, at $1 \%$ and $5 \%$ level. However, in the long run unemployment is associated with economic growth, similarly, FDI and labour force participation rate seems to have long run interdependence.

The previous studies found to have significant positive impact of labour and capital and negative impact of inflation and unemployment on GDP. Correlation matrix depicts economic growth to have positive correlation with capital formation, money supply, and trade and negative correlation with labour-force, inflation, FDI and unemployment. Bound test further confirms the co-integration among the variables.

\section{References}

Abbas, S. (2012). Causality between Exports and Economic Growth: Investigating Suitable Trade Policy for Pakistan. Eurasian Journal of Business and Economics , 5 (10), 91-98.

Ademola, A. S., \& Badiru, A. (2016). The Impact of Unemployment and Inflation on Economic Growth in Nigeria (1981-2014). International Journal of Business and Economic Sciences Applied Research , 9 (1), 47-55.

Ali, S. (2014). Inflation, Income Inequality and Economic Growth in Pakistan: A Cointegration Analysis. International Journal of Economic Practices and Theories , 4 (1), 33-42.

Balassa, B. (1985). Exports, policy choices, and economic growth in developing countries after the 1973 oil shock. Journal of Development Economics , 18 (1), 23-35.

Chughtai, M. W., Malik, M. W., \& Aftab, R. (2015). Impact of Major Economic Variables on Economic Growth of Pakistan. Acta Universitatis Danubius , 11 (2), 94-106.

Falki, N. (2009). Impact of Foreign Direct Investment on Economic Growth in Pakistan. International Review of Business Research Papers , 5 (5), 110-120.

Gudaro, A. M., Chhapra, I. U., \& Sheikh, S. A. (2010). Impact of Foreign direct Investment on Economic Growth: A Case Study of Pakistan. Journal of Management and Social Sciences , 6 (2), 84-92.

Hameed, I., Iqbal, A., \& Devi, K. (2012). Relationship between Exports and Economic Growth of Pakistan. European Journal of Social Sciences , 32 (3), 453-460.

Hussain, T., Siddiqi, W. M., \& Iqbal, A. (2010). A Coherent Relationship between Growth and Unemployment: An Empirical Evidence from Pakistan. International Journal of Economics and Management Engineering , 4 (3), 288-295.

Ilyas, M., Sabir, H. M., Shehzadi, A., \& Shoukat, N. (2014). Inter-relationship among Economic Growth, Savings and Inflation in Pakistan. Journal of Finance and Economics , 2 (4), 125-130.

Kibria, U., Arshad, M. U., Kamran, M., \& Mehmood, Y. (2014). Exploring the Impact of Macro Economic Variables on GDP Growth of Pakistan. Research Journal of Management Sciences , 3 (9), 1-6.

Mahmood, Y., Bokhari, R., \& Aslam, M. (2013). Trade- off between Inflation, Interest and Unemployment rate of Pakistan: A Cointegration Analysis. Pakistan Journal of Commerce and Social Sciences , 7 (3), $482-$ 492.

Mosikari, T. J. (2013). The effect of Unemployment rate on Gross domestic product case of South Africa. Mediterranean Journal of Social Sciences , 4 (6), 429-434.

Omoniyi, L. G., \& Olawale, A. N. (2015). An Application of ARDL Bounds Testing Procedure to the Estimation of Level Relationship between Exchange Rate, Crude Oil Price and Inflation Rate in Nigeria. International Journal of Statistics and Applications , 5 (2), 81-90.

Pesaran, M.H., Shin, Y. \& Smith, R J. (1999). Pooled mean group estimation of dynamic heterogeneous panels. Journal of the American Statistical Association, 94 (446), 621-634.

Pesaran, M.H., Shin, Y. \& Smith, R. J. (2001). Bounds testing approach to the analysis of level relationships. Journal of Applied Econometrics, 16(3), 289-326.

Pradhan, R. P., Arvin, M. B., Hall, J. H., \& Bahmani, S. (2014). Causal nexus between economic growth, banking sector development, stock market development, and other mcroeconomic variable: The case of ASEAN countries. Review of Financial Economics , 23 (4), 155-173.

Saaed, A. A., \& Hussain, M. A. (2015). Impact of Exports and Imports on Economic Growth: Evidence from Tunisia. Journal of Emerging Trends in Economics and Management Sciences , 6 (1), 13-21. 
Samargandi, N., Fidrmuc, J., \& Ghosh, S. (2015). Is the Relationship Between Financial Development and Economic Growth Monotonic? Evidence from a Sample of Middle-Income Countries. World Development , 68, 66-81.

Saymeh, A. A., \& Orabi, M. M. (2013). The effect of interest rate, inflation rate, GDP on real Economic Growth rate in Jordan. Asian Economic and Financial Review, 3, 341-354.

Shahid, M. (2014). Effect of Inflation and Unemployment on Economic Growth in Pakistan. Journal of Economics and Sustainable Development , 5 (15), 103-106.

Stamatiou, P., \& Dritsakis, N. (2013). A Causal Relationship between Exports, Foreign Direct Investment and Economic Growth for five European countries. A panel data approach. Conference: Proceedings of 12th Annual European Economics and Finance Society (EEFS) Conference, At Berlin, Germany.

Ullah, I., Shah, M., \& Khan, F. U. (2014). Domestic investment, foreign direct investment, and economic growth nexus: A case of Pakistan. Economics Research International , 1-5.

Yaqub, R. M., Ali, S., \& Haq, I. (2016). Impact of Foreign Direct Investment and Exports on. Developing Country Studies , 6 (1), 78-86.

Yelwa, M., David, O. O., \& Awe, E. (2015). Analysis of the relationship between Inflation, Unemployment and Economic Growth in Nigeria: 1987-2012. Applied Economics and Finance, 2 (3), 102-109.

Abbas, S. 2012, Causality between exports and economic growth: Investigating suitable trade policy for Pakistan. Eurasian Journal of Business and Economics, vol. 5, pp. 91-98.

Ademola, A. and Badiru, A. 2016, The impact of unemployment and inflation on economic growth in Nigeria (1981-2014). International Journal of Business and Economic Sciences Applied Research, 9(1).

Ali, S., 2014, Inflation, income inequality and economic growth in Pakistan: A co-integration analysis. International Journal of Economic Practices and Theories, vol. 4, no. 1, pp. 33-42.

Balassa, B. 1985, Exports, policy choices, and economic growth in developing countries after the 1973 oil shock. Journal of development economics, vol. 18, no. 1, pp. 23-35.

Chughtai, M.W., Malik, M.W. and Aftab, R. 2015, Impact of Major Economic Variables on Economic Growth of Pakistan. ActaUniversitatisDanubius: Oeconomica, vol. 11, no. 2.

Falki, N. 2009, Impact of foreign direct investment on economic growth in Pakistan. International Review of Business Research Papers, vol. 5, no. 5, pp.110-120.

Gudaro, A.M., Chhapra, I.U. and Shaikh, S.A. 2010, Impact of foreign direct investment on economic growth: A case study of Pakistan. IBT Journal of business studies JBS), vol. 6, no. 2.

Hameed, I., Iqbal, A. and Devi, K. 2012, Relationship between exports and economic growth of Pakistan. European Journal of Social Sciences, vol. 32 no. 3, pp. 453-460.

Hussain, T., Siddiqi, M.W. and Iqbal, A. 2010, A coherent relationship between economic growth and unemployment: An empirical evidence from Pakistan.

Hussain, M.A. and Saaed, A.A.J. 2015, Impact of exports and imports on economic growth: Evidence from Tunisia. Journal of Emerging Trends in Economics and Management Sciences, vol. 6, no.1, pp.13-21.

Ilyas, M., Sabir, H.M., Shehzadi, A. and Shoukat, N. 2014, Inter-relationship among economic growth, savings and inflation in Pakistan. Journal of Finance and Economics, vol. 2, no. 4, pp.125-130.

Kibria, U. 2014, Exploring the Impact of Macro Economic Variables on GDP growth in Pakistan. Research Journal of Management Sciences, vol. 3, no. 9, pp.1-6.

Mahmood, Y., Bokhari, R. and Aslam, M 2013, Trade-off between inflation, interest and unemployment rate of Pakistan: A cointegration analysis. Pakistan Journal of Commerce and Social Sciences (PJCSS), vol.7, no. 3, pp. 482-492.

Mosikari, T.J., 2013, The effect of unemployment rate on gross domestic product: Case of South Africa. Mediterranean Journal of Social Sciences, vol. 4, no. 6, pp. 429-434.

Omoniyi, L.G. and Olawale, A.N., 2015, An application of ARDL bounds testing procedure to the estimation of level relationship between exchange rate, crude oil price and inflation rate in Nigeria. International Journal of Statistics and Applications, vol. 5 no. 2, pp. 81-90.

Pesaran, M.H., Shin, Y. and Smith, R.P., 1999, Pooled mean group estimation of dynamic heterogeneous panels, Journal of the American Statistical Association, vol. 94, no. 446, pp. 621-634.

Pesaran, M.H., Shin, Y. and Smith, R.J., 2001, Bounds testing approaches to the analysis of level relationships. Journal of applied econometrics, vol.16, no. 3, pp. 289-326.

Pradhan, R.P., Arvin, M.B., Hall, J.H. and Bahmani, S., 2014, Causal nexus between economic growth, banking sector development, stock market development, and other macroeconomic variables: The case of ASEAN countries. Review of Financial Economics, vol. 23, no. 4, pp.155-173. 
Samargandi, N., Fidrmuc, J. and Ghosh, S., 2015, Is the relationship between financial development and economicgrowth monotonic? Evidence from a sample of middle-income countries. World Development, vol. 68, pp. 66-81.

Saymeh, A.A.F. and Orabi, M.M.A., 2013, The effect of interest rate, inflation rate, GDP, on real economic growth rate in Jordan. Asian Economic and Financial Review, vol. 3, no. 3, pp. 341.

Shahid, M., 2014, Effect of inflation and unemployment on economic growth in Pakistan. Journal of economics and sustainable development, vol. 5, no.15, pp.103-106.

Stamatiou, P. and Dritsakis, N., 2013, A Causal Relationship between Exports, Foreign Direct Investment and Economic Growth for five European countries: A Panel Data Approach. Twelfth Annual EEFS Conference, Berlin, Germany.

Ullah, I., Shah, M. and Khan, F.U., 2014, Domestic investment, foreign direct investment, and economic growth nexus: A case of Pakistan. Economics Research International, pp. 1-5.

Yaqub, R.M.S., Ali, S. and Haq, I., 2016, Impact of Foreign Direct Investment and Exports on Economic Growth of Pakistan. Developing Country Studies www.iiste.org ISSN 2224-607X (Paper) ISSN $2225-$ 0565 (Online) vol.6, no.1.

Yelwa, M., David, O.O. and Awe, E.O 2015, Analysis of the relationship between inflation, unemployment and economic growth in Nigeria: 1987-2012. Applied Economics and Finance, vol.2, no.3, pp.102-109. 